Bangl. J. Vet. Med. (2006). 4 (2): 103-106

\title{
PREVALENCE OF AMPHISTOMES IN BLACK BENGAL GOATS IN MYMENSINGH DISTRICT
}

\author{
M. Z. Uddin ${ }^{1}$, T. Farjana ${ }^{*}$, N. Begum and M. M. H. Mondal \\ Department of Parasitology, Faculty of Veterinary Science, Bangladesh Agricultural University, Mymensingh- \\ 2202, Bangladesh \\ *Corresponding author's e-mail address : tfarjanamunni@yahoo.com
}

\begin{abstract}
To investigate the prevalence of amphistome parasites in Black Bengal goats slaughtered at different slaughterhouses of Mymensingh district, a total of 144 gastro-intestinal tracts were examined during the period of July 1998 to June 1999 in the Department of Parasitology, Bangladesh Agricultural University, Mymensingh. Out of 144 Black Bengal goats, 105 (72.92\%) were infected with a single or multiple species of amphistomes. In present investigation, three species of amphistomes viz Paramphistomum cervi, Cotylophoron cotylophorum and Gastrothylax crumenifer were identified. The highest infection was observed with Paramphistomum cervi (65.28\%) and lowest infection with Cotylophoron cotylophorum (36.11\%). Mixed infections with two or more species of amphistomes were found in $60.42 \%$. Age had a significant $(p<0.01)$ influence on the prevalence of amphistomes in goat. A higher prevalence (89.58\%) was observed in older animals followed by young animals $(78.57 \%)$, whereas a lower prevalence $(45.0 \%)$ in growing animals. However, the prevalence increased with the increase of age. The females $(75.0 \%)$ were found more (1.44 times) susceptible to amphistomes infection than the males $(67.5 \%)$. The prevalence of amphistomes was very high all the year round and the rate of infection was $83.64 \%, 69.23 \%$ and $64.0 \%$ during monsoon, winter and summer season respectively. The present study concluded that Black Bengal goats are susceptible to amphistome infection irrespective of age, sex and season of the year. So, control of these parasites is essential and the further investigation is needed, focusing on control procedures of amphistomes infection in goats.
\end{abstract}

Key Words: Amphistomes, prevalence, Black Bengal goats

\section{INTRODUCTION}

In Bangladesh, among many other causes, parasitism is thought to be a major cause that hindering the development of livestock population (Jabber and Green, 1983). The losses due to parasitism take in the form of mortality, poor health condition, retarded growth, lower output of work, decrease in the production of milk and meat (Faiz, 1972). The geo-climatic conditions together with the water-lodged and low-lying areas in Bangladesh are conducive to parasitic diseases in domestic ruminants. Goats are known to suffer from many helminthic diseases of which paramphistomiasis is one of them. In ruminants, paramphistomiasis has been found to be associated with diarrhoea, loss of body condition, rough hair coat, dullness, weakness, loss of appetite, intestinal haemorrhages, anaemia, reduced milk production and intermandibular swelling (Chandrasekharan et al., 1982; Blood et al., 1983). A very few investigation was done on the prevalence of amphistome parasites in goat (Haq and Shaikh, 1968; Rahman, 1969), however, the prevalence of amphistomiasis in goat in association with age, sex and season has not been studied properly yet in goats in Bangladesh. Therefore, in this study, an attempt was made to record the prevalence of amphistome parasites in Black Bengal goats associated with the influence of age and sex on the prevalence and to correlate between worm burden and seasonal changes.

\section{MATERIALS AND METHODS}

This study was carried out in the Department of Parasitology, Bangladesh Agricultural University, Mymensingh, during the period from July 1998 to June 1999.

Present address: ${ }^{1}$ Veterinary Surgeon, Upazila Veterinary Hospital, Manikgonj Sadar, Manikgonj. 


\section{Collection of viscera and description of animals}

The entire digestive tract of 144 Black Bengal goats of both sexes (40 males and 104 females) were collected from different slaughter houses of various localities of Mymensingh district. According to the age, animals were grouped into growing animals (6-12 months old); young animals (12-24 months old) and older animals (above 24 months old).

\section{Recording of seasons}

For convenience of the study, the whole year was grouped into 3 different seasons comprised to the winter (December to February), the summer (March to June) and the monsoon (July to October).

\section{Collection and identification of the parasites}

The parasitic counts of gastro intestinal contents and washings of the viscera were made by the methods followed by Skeurman and Hillard (1966) with some modifications. The amphistomes were preliminarily identified under microscope using low power objectives and then permanent slides of amphistomes were prepared by Semichon's carmine staining for detailed morphological studies and identification.

\section{Statistical analysis}

The overall prevalence and the influence of age on the prevalence of amphistomes were analyzed by Chisquare test. The test was done following the methods described by Mostafa (1989). Odds ratio for the influence of sex and season on the prevalence was obtained by the formula according to the Schlesselman (1982).

\section{RESULTS AND DISCUSSION}

Of 144 animals examined, 105 were found infected with amphistomes, resulting an overall infection rate of $72.92 \%$. Three species of amphistomes viz. Paramphistomum cervi, Cotylophoron cotylophorum and Gastrothylax crumenifer were recorded in this study (Table 1).

Table 1. The percentage of infection with different species of amphistomes in Black Bengal goats in Mymensingh district

\begin{tabular}{|c|c|c|c|c|c|}
\hline \multirow[t]{2}{*}{ Species identified } & \multicolumn{2}{|c|}{$\begin{array}{l}\text { Infected goats } \\
(\mathrm{n}=144)\end{array}$} & \multicolumn{2}{|c|}{ Odds ratio } & \multirow[t]{2}{*}{ Value of $\chi^{2}$} \\
\hline & No. & $\%$ & & & \\
\hline Paramphistomum cervi & 94 & 65.28 & & & \\
\hline Gastrothylax crumenifer & 78 & 54.17 & 1.59 & P. cervi vs G. crumenifer & \\
\hline Cotylophoron cotylophorum & 52 & 36.11 & 3.33 & P. cervi vs C. cotylophorum & $28.31 *$ \\
\hline $\begin{array}{l}\text { Mixed infection with } \\
\text { two or more species }\end{array}$ & 87 & 60.42 & 1.23 & P. cervi vs mixed infection & \\
\hline
\end{tabular}

*Stands for significant at $1 \%$ level of significance, $n=$ Number of goats examined.

A relatively higher prevalence was recorded with Paramphistomum cervi (65.28\%), followed by Gastrothylax crumenifer (54.17\%) and lower with Cotylophoron cotylophorum (36.11\%) and mixed infection with two or more species was found $60.42 \%$ (Table 1). The proportions of infected animals corresponding to the different species of amphistomes exerted a statistically significant difference among themselves and the odds ratios of Paramphistomum cervi against Gastrothylax crumenifer, Cotylophoron cotylophorum and mixed infection are 1.59, 3.33 and 1.23 respectively (Table 1). So it can be say that the risk of being infected of a Black Bengal goat of the species of Paramphistomum cervi is higher than that of any other species of amphistomes. Availabilty of intermediate snail host of the Paramphistomum cervi in the research area may be one of the causes of high susceptibility of Paramphistomum cervi infection in goats and it may be due to some genetic factor. In this investigation, the prevalence of amphistomes was much higher than those reported from Bangladesh by Haq and Shaikh (1968) and Rahman (1969), which were 60\% and 8\% respectively and by 
Prevalence of amphistomes in goats

Mohiuddin et al. (1982) from Pakistan (15.3\%), Manna et al. (1994) from West Bengal (51.8\%) and Azad (1997) from Baluchistan (13.5\%). This variation in the prevalence of amphistomes in goats may be due to agroecological conditions, animal husbandry practices, breeds of animal, prevalence of intermediate snail hosts etc.

Table 2. Age wise prevalence of amphistomes in Black Bengal goats in Mymensingh district

\begin{tabular}{|lllll|}
\hline Age groups & $\begin{array}{l}\text { No. of goats } \\
\text { examined }\end{array}$ & \multicolumn{2}{l}{ Goats infected } & \multirow{2}{*}{ Value of $\chi^{2}$} \\
\cline { 3 - 4 } & & No. & $\%$ & \\
\hline Growing goats (6-12 months) & 40 & 18 & 45.00 & \\
Young goats (12-24 months) & 56 & 44 & 78.57 & $23.46^{*}$ \\
Older goats ( $>24$ months) & 48 & 43 & 89.58 & \\
\hline
\end{tabular}

*Stands for significant at $1 \%$ level of significance.

Table 3. Sex wise prevalence of amphistomes in Black Bengal goats in Mymensingh district

\begin{tabular}{|c|c|c|c|c|}
\hline \multirow[t]{2}{*}{ Sex } & \multirow{2}{*}{$\begin{array}{l}\text { No. of goats } \\
\text { examined }\end{array}$} & \multicolumn{2}{|c|}{ Goats infected } & \multirow{2}{*}{$\begin{array}{l}\text { Odds ratio of female } \\
\text { against male }\end{array}$} \\
\hline & & No. & $\%$ & \\
\hline Male & 40 & 27 & 67.50 & \multirow[b]{2}{*}{1.44} \\
\hline Female & 104 & 78 & 75.00 & \\
\hline Overall & 144 & 105 & 72.92 & \\
\hline
\end{tabular}

- Female goats are 1.44 times more likely to be infected than male goats.

Table 4. Seasonal prevalence of amphistomes in Black Bengal goats in Mymensingh district

\begin{tabular}{|c|c|c|c|c|}
\hline \multirow[t]{2}{*}{ Seasons } & \multirow{2}{*}{$\begin{array}{l}\text { No. of goats } \\
\text { examined }\end{array}$} & \multicolumn{2}{|c|}{ Goats infected } & \multirow[t]{2}{*}{ Odds ratio } \\
\hline & & No. & $\%$ & \\
\hline Summer (March to June) & 50 & 32 & 64.00 & 2.88 (Monsoon vs Summer) \\
\hline Monsoon (July to October) & 55 & 46 & 83.64 & 2.27 (Monsoon vs Winter) \\
\hline Winter (November to February) & 39 & 27 & 69.23 & 1.27 (Winter vs Summer) \\
\hline
\end{tabular}

In this study, age had a significant $(\mathrm{p}<0.01)$ association with the prevalence of amphistomes. The highest prevalence (89.58\%) was recorded in older animals ( $>24$ months), followed by $78.57 \%$ in young animals $(12-24$ months) and the lowest (45.0\%) in growing animals of 6-12 months old (Table 2). This result is in agreement with the earlier findings of Okafor et al. (1988) and Mohiuddin et al. (1982) who reported that there was an age limit in the prevalence of amphistomes and heavy infection was found in goats more than two years of age. The reason in the prevalence of infection in different age groups in goats is difficult to explain but it might be due to an immunological phenomenon. Besides, higher prevalence in older groups may be due to more exposure to the source of infection. This study revealed a relatively higher (1.44 times more) prevalence in females $(75.00 \%)$ than males $(65.50 \%)$ (Table 3$)$. This finding is very difficult to compare due to unavailability of published literature in goat. However, Saifuzzaman (1996) reported the percentage of infection in cattle population among male and female animals were $45.54 \%$ and $55.56 \%$ respectively. The higher percentage of infection in the females may be due to the alteration in the physiological condition of the animals during pregnancy and lactation (production activity) and also the lack of feed supplement for production, which may lead to the lowering of body resistance of the females. 
A slightly higher prevalence $(83.64 \%)$ was recorded during monsoon followed by winter $(69.23 \%)$ and lower $(64.0 \%)$ in summer which is closely related to the reports of Petkov et al. (1988) and Okafor et al. (1988). Calculated odds ratio implied that goats were 2.88 and 2.27 times more susceptible to amphistome infection in monsoon than summer and winter respectively. But in winter season goats were 1.27 times more likely to be infected than summer (Table 4). In Bangladesh, first raining starts at late summer and at that time, aestivated snails becomes reactivated and dispersed through the fields and pasture by the rain, and becomes infected with miracidia of amphistomes. In the snail, radiae undergo marked growth by the twenty first day of infection, cercariae are released and require thirteen days for become metacercariae (Soulsby, 1982). So, goats were infected by the metacercariae mostly in the early monsoon. The pre-patent period of amphistomes varies from 710 weeks depending upon the parasite species (Urquhart et al., 1996). That's why mature amphistomes were mostly prevalent in monsoon. Metacercariae remain viable for 3 months (Soulsby, 1982) and continue their infection in goats in the winter. There is no evidence of auto expulsion of amphistomes from the host body and this is the reason behind the year round prevalence of amhistomes in goats. However, Manna et al. (1994) reported that the highest incidence of amphistomes was in the summer season in West Bengal. This variation might be due to geographical and different climatic factors such as temperature, rainfall, humidity etc.

The present study clearly indicates that amphistome infection in Black Bengal goats irrespective of age, sex and season of the year is a problem that can play a role in hindering the livestock development in the country. So, development of sustainable cost effective control strategies against amphistome parasites is essential and to achieve that, the further investigation is needed.

\section{REFERENCES}

1. Azad E, khan SA, Khan RM and Khan MM (1997). Prevalence of gastro-intestinal helminth parasites of sheep and goats in Quetta district of the province of Baluchistan, Pakistan. Pakistan Journal of Zoology 29: 259-262.

2. Blood DC, Radostits OM and Henderson JA (1983). Veterinary Medicine. $6^{\text {th }}$ edn., ELBS, Bailliere and Tindall, UK. pp. 906-907.

3. Chandrasekharan K, Radhakrishnan K and Jacob VC (1982). Efficacy of Distodin in the treatment of amphistomiasis in Indian elephants. Kerala Journal of Veterinary Science 13: 55-58.

4. Faiz MA (1972). Report on 'Investigation into the epidemiology of parasitic disease in East Pakistan'. In: Activities of the Research sections of Directorate of Livestock Services Bangladesh. 1968-1972.

5. Haq S and Shaikh H (1968). A survey of helminths parasiting the gastro-intestinal tract of goats and sheep in East Pakistan. Pakistan Journal Veterinary Science 2: 54-62.

6. Jabber M and Green DAG (1983). The status and potential of livestock within the context of agricultural development policy in Bangladesh. Inaugural-Dissertation. The University of Wales. Aberystwyth, UK. P-113.

7. Manna AK, Pramanik S and Mukherjee GS (1994). Incidence of paramphistomiasis in west Bengal. Indian Journal of Animal Health 33: 87-89.

8. Mohiuddin A, Khan MM, Mughal FA and Sheikh MA (1982). Prevalence of amphistomiasis in sheep and goats in Sind, Pakistan. Pakistan Veterinary Journal 2: 17-18.

9. Mostafa MG (1989). Methods of Statistics, $4^{\text {th }}$ edn., Karim Press and Publications, Dhaka, Bangladesh.

10. Okafor FC, Mbata G and Anosike J (1988). Studies on Paramphistomum cervi infections of ruminants in Imo state, Nigeria with special reference to the role played by Bulinus b. forskalii (Ehrenberg) in their transmission. Bulletin of Animal Health and Production in Africa. 38: 142-146.

11. Petkov A, Rusev I, Ignafov G, Toncheva V and Mikhailov Z (1988). Epidemiological control, early chemoprophylaxis and treatment of ovine fascioliasis. Veterinarna Sbirka 86: 42-44.

12. Rahman MH (1969). Taxonomic studies on the helminth parasites encountered in the abomasum of ruminants in East Pakistan. M. Sc. (Vet. Science) Thesis. Department of Parasitology, East Pakistan Agricultural University, Mymensingh.

13. Saifuzzaman ABM (1996). Incidence and seasonal variation of helminth parasites of cattle of chandina Thana in Comilla district. MSc. Thesis. Department of Parasitology, Bangladesh Agricultural University, Mymensingh.

14. Schlesselman JJ (1982). Case Control Studies: Design, Conduct, Analysis. $2^{\text {nd }}$ edn., Oxford University Press, Oxford pp. 174-177.

15. Skeurman KD and Hillard JJ (1966). A hand book for studies of helminth parasites of ruminates. Near East Animal Health Institute Hand book No. 2, FAO of the United Nations, Beirut, Lebanon.

16. Soulsby EJL (1982). Helminths, Arthropods and Protozoa of Domesticated Animals. $7^{\text {th }}$ edn., Bailliere Tindall, London.

17. Urquhart GM, Armour J, Duncan JL, Dunn AM and Jennings FW (1996). Veterinary Parasitology. $2^{\text {nd }}$ edn., Blackwell Science Ltd. p. 115. 